\title{
Response to Inbreeding of Seedling Traits in a Prunus domestica L. Breeding Population
}

\author{
Carolyn J. DeBuse', Douglas V. Shaw, and Theodore M. DeJong \\ Department of Pomology, University of California, Davis, CA 95616
}

AdDitional INDEX WORDs. inbreeding depression, polyploidy, european plum, prune

\begin{abstract}
Controlled pollinations were made using 20 elite selections from the University of California, Davis, Prunus domestica (european plum) breeding program as parents. These parents were used to generate 11 self-pollinated progenies with an inbreeding coefficient $(F)$ of 0.5 , 10 full-sibling progenies $(F=0.25)$, and 11 progenies from among nonrelated parents $(F=0)$. Seven additional progenies were chosen as a random-mating control set within the parental group; progenies in the control set had accumulated a range of current inbreeding coefficients (average $F=0.23$ ) over two to five generations with intervening cycles of selection. Survival percentages were 85, 82, and 74 for the full-sib progeny, control set progeny, and selfed progeny, respectively, relative to nonrelated progeny. Two months after germination the percent decrease in the growth trait means for the selfed progeny compared to the nonrelated progeny ranged from $14 \%$ to $30 \%$ whereas growth trait means for full-sib progeny decreased from $1 \%$ to $9 \%$ compared to nonrelated progeny. The percent decrease for growth trait means of the selfed progeny after completing one season of growth in the field (10 months) was similar to that observed after 2 months, ranging from $14 \%$ to $28 \%$ compared to nonrelated progeny, whereas the decrease in full-sib progeny trait means was somewhat greater, ranging from $6 \%$ to $20 \%$. Regression analysis of all growth traits on current-generation rates of inbreeding indicated a significant negative linear relationship $(P=0.0011$ to 0.0232$)$. No significant relationships were found between accumulated Fs and growth trait means of the control set progenies and the nonrelated progenies after 2 months in the greenhouse or one season growing in the field, suggesting that selection between breeding cycles decreased inbreeding depression.
\end{abstract}

The Prunus domestica (european plum) breeding program at the Univ. of California, Davis (UCD), was established in 1985 with the support of the California Dried Plum Board. The goal of the program is to increase the number of cultivars available to the California industry that have fruit quality equivalent to, or higher than, the current industry standard cultivar, Improved French, but with progressive fruit maturity dates to facilitate the efficiency of harvest and processing. The high standards set by 'Improved French' and the climate of California restricted the initial elite germplasm available to the breeding program to only a few well-adapted parental cultivars. These restrictions on parental material resulted in an initial population containing few genotypes in its immediate ancestral background. In addition, the breeding strategy of the program in early generations relied heavily on 'Improved French' as a parent. Although this genotype has many favorable characteristics, using it as a principle parent increased both relatedness and inbreeding in this population. The population structure generated by this breeding strategy could have deleterious long term consequences for desired traits if inbreeding depression is an ultimate consequence of necessary matings among relatives.

The primary consequence of inbreeding is an increase in the homozygosity within an individual or population. This occurs when a common ancestor contributes both alleles that are present in a diploid individual, and its alleles are thus identical by decent. The genetic consequences of inbreeding are usually quantified using the inbreeding coefficient, which is defined as the probability that any diploid locus contains two alleles that are identical by descent from a common ancestor. Inbreeding depression can be defined as an observed reduction in the mean of a metric trait in a population due to mating among relatives. It is usually associated with lower vigor, fertility, and survival of an inbred individual

Received for publication 6 Apr. 2005. Accepted for publication 26 June 2005. 1To whom reprint requests should be addressed.E-mail address: cjdebuse@ucdavis. edu or population. Reduction in the population mean results from an increase in the frequency of the homozygous genotypes together with partial or complete dominance at the loci governing the trait (Falconer and Mackay, 1996).

The magnitude of inbreeding depression for any trait can be measured by estimating the regression coefficient of the population mean on the inbreeding coefficient, $F$. This linear relationship is described in the formula $Y=a+b(F)+\varepsilon$, where $Y$ represents the value of the phenotype, a the intercept, $\mathrm{b}$ the slope, and $\mathrm{F}$, leaving $\varepsilon$ as the residual (Williams and Savolainen, 1996).

Inbreeding depression has been observed for yield of agriculture crops such as strawberry (Fragaria $\times$ ananassa Duch.), maize (Zea mays L.), sunflower (Helianthus annuus L.), onion (Allium cepa L.), and carrot (Daucus carota L.) (Bringhurst and Voth, 1984; Cornelius and Dudley, 1974; Jones and Bingham, 1995; Morrow and Darrow, 1952; Shaw, 1995, Shaw, 1997). A negative linear relationship between the population mean and $\mathrm{F}$ has been shown in strawberry for yield, plant size, and fruit size (Shaw, 1995) and in douglas-fir [Pseudotsuga menziesii (Mirb.) Franco] for seedling size (Sorensen, 1997). In forestry, inbred populations express decreased height, diameter, germination rates, and seed fill in numerous tree species (Cram, 1984; Griffin and Cotterill, 1988; Hedrick et al., 1999; Koelewijn et al., 1999; Libby et al., 1981; Sniezko and Zobel, 1987; Sorensen, 1997; Sorensen and Miles, 1974). Inbreeding depression has also been detected in the genus Prunus L.; Hrotkó and Magyar (1998) demonstrated a reduction in plant vigor after self-fertilizing P. mahleb $\mathrm{L}$. for three generations.

The consequences of inbreeding for $P$. domestica are difficult to predict, as $P$. domestica has several characteristics that may mitigate inbreeding depression, including the capacity for both cross-fertilized and self-fertilized pollinations. Selfing species typically exhibit lower levels of inbreeding depression than crossfertilized species (Fehr, 1991). Prior natural self-fertilizations in ancestral populations of $P$. domestica and its wild relatives may have reduced the frequency of less favorable recessive alleles, and 
thus reduced the magnitude of inbreeding depression found in the species at present. Furthermore, P. domestica is an allohexaploid having the interspecific ancestral parentage of $P$. cerasifera Ehrh. X P. spinosa L. (Bortiri et al., 2001; Mowrey and Werner, 1990). Inbreeding depression may be buffered in allopolyploids due to the presence of duplicate genes in the divergent genomes, although inbreeding studies of allopolyploids such as strawberry, a modern interspecific auto-allo-octoploid (Bringhurst and Voth, 1984; Shaw, 1995) and redwood [Sequoia sempervirens (Lamb. ex D. Don) Endl.], an ancient allohexaploid (Libby et al., 1981) have demonstrated that inbreeding depression can occur in polyploid species at magnitudes similar to that observed for diploids.

Both natural and artificial selection, with consequent allele frequency changes, can affect the expression of inbreeding depression in a population (Falconer and Mackay, 1996). Shaw (1997) demonstrated that inbred strawberry offspring selected between cycles of recurrent inbreeding had greater yields than their nonselected counterparts. Natural selection also was shown to decrease inbreeding depression for larval viability and adult fecundity in Drosophila melanogaster Meigen populations (Ehiobu et al., 1989). In our study population, parental trees had been selected for fruit characteristics and vigorous growth habits during previous breeding cycles, a practice that may have affected homozygosity and modified the relationship of predicted pedigree and realized inbreeding coefficients. The realized frequency of homozygotes may not have accumulated at the rate expected due to inbreeding alone.

The primary objective of this study was to estimate the magnitude of inbreeding depression for seed germination rate and seedling growth traits in the UCD P. domestica breeding population with current-generation inbreeding treatments of self-pollinations, full-sibling crosses and nonrelated progenies. Because selection can affect the relationship between pedigree $\mathrm{F}$ and realized changes in trait means, a second objective of this study was to determine whether pedigree inbreeding coefficients accumulated over multiple generations with intervening cycles of selection accurately predict trait mean changes for the same seedling growth traits.

\section{Materials and Methods}

Twenty parent trees were chosen from the UCD $P$. domestica breeding population. Each parent tree had at least one full sibling within the group of 20, thus this parental set included eight related subgroups. Pollinations were made among these parent trees to create progenies with three levels of current-generation inbreeding: 11 self-pollinated progenies, 10 full-sibling progenies (full-sib progenies), and 11 progenies from among nonrelated parents (nonrelated progenies). Seven additional progenies were chosen as a control set (control progenies) from randomly-mated trees within the parental group. This control set was indirectly a separate inbreeding treatment, and represented crosses that had accumulated their current levels of inbreeding over multiple generations of mating with intervening cycles of selection.

Inbreeding coefficients due to current generation matings for selfed progenies, full-sib progenies, and nonrelated progenies were thus $0.50,0.25$, and 0.0 , respectively (Falconer and Mackay, 1996). The accumulated inbreeding coefficients of the nonrelated progenies and the control progenies were also calculated using SAS Procedure Inbreed (SAS, 1999). The 20 experimental parental trees originated from nine parent trees that subsequently originated from sixteen grand-parent trees which came from diverse germ- plasm collections. Due to finite population size in the breeding population, it was not possible to construct completely nonrelated progenies. On average, the cumulative inbreeding coefficient for the progenies intended as nonrelated was $\mathrm{F}=0.0909$ where none of this inbreeding was generated in the current mating cycle. The control progenies had values for cumulative $F$ ranging from 0.1875 to 0.3438 , with the average $F=0.2299$.

Pollinations were done, in Spring 2001, at the Kearney Agricultural Center in Parlier, Calif. (lat. 36 $46^{\prime} \mathrm{N}$, long. $119^{\circ} 43^{\prime} \mathrm{W}$ ). The fruit was collected $10 \mathrm{~d}$ before full maturity (30 July to 25 Aug. 2001) and stored at $4.0^{\circ} \mathrm{C}$ for $30-57 \mathrm{~d}$. The seeds were then removed from the fruit, air-dried, and stored at $4.0^{\circ} \mathrm{C}$ until 19 Nov. 2001. Seeds were stratified beginning 19 Nov. 2001. Stratification was completed by storing the fully-imbibed seeds between sheets of paper towel dampened with water containing fungicide $\left(45 \%\right.$ thiram at $\left.45 \mathrm{~mL} \cdot \mathrm{L}^{-1}\right)$ and antibiotic $\left(50 \mathrm{mg} \cdot \mathrm{L}^{-1}\right.$ tetracycline), enclosing them in plastic bags, and storing them at $4.0{ }^{\circ} \mathrm{C}$ for a minimum of $1800 \mathrm{~h}$.

After stratification (20 Feb. 2002) the outer seed integument was removed, and each seed was planted into an individual plastic cone containing moist potting soil. The trays were placed under intermittent mist in a greenhouse for $7 \mathrm{~d}$. A germination study was conducted using all the progenies. Seed numbers per progeny ranged from 13 to 205 . The number of seeds that had germinated after $10 \mathrm{~d}$. was recorded for each progeny and differences among inbreeding treatments were tested using chi-square for homogeneity over inbreeding levels.

After germination, seedlings were removed from the mist and 12-60 offspring were randomly sampled from each of the 39 progenies. These offspring were established in a randomized complete-block design with four blocks. Each block contained an equal number of offspring from each progeny, arranged in noncontiguous plots (Libby and Cockerham, 1980). The initial evaluation of seedling growth traits was conducted in a naturally-lighted greenhouse. Seedlings were arranged in the trays 8 $\mathrm{cm}$. from any neighboring seedling to minimize competition for light; they were fertilized weekly $\left(20 \mathrm{~N}-8.8 \mathrm{P}-16.6 \mathrm{~K}\right.$ at $\left.4 \mathrm{~g} \cdot \mathrm{L}^{-1}\right)$, and were protected from insects and fungus. Measurements of seedling height, trunk diameter at soil level, and branch lengths were recorded 2 months after germination. These measurements were combined to form four variables for further analysis; 1 ) 2-month radius (diameter/2), 2) 2-month height, 3) combined branch and trunk length, and 4) a 2-month growth index [(radius $)^{2} \times$ height].

After recording measurements at 2 months (9 May 2002), the experimental seedlings were removed from the greenhouse and planted in a commercial nursery, near Newcastle, Calif. (lat. $38^{\circ} 52^{\prime} \mathrm{N}$, long. $\left.121^{\circ} 7.92^{\prime} \mathrm{W}\right)$. Prior to planting, the soil was fumigated $\left(1,3\right.$-dichloropropene $\left.326 \mathrm{~L} \cdot \mathrm{ha}^{-1}\right)$ followed by an application of phosphate $\left(8.8 \mathrm{P}\right.$ at $\left.446 \mathrm{~kg} \cdot \mathrm{ha}^{-1}\right)$. No additional fertilizer was applied during the growing season. The experimental design was unchanged from the greenhouse; thus any block effects observed for the outdoor nursery portion of the trial could have been carried over from the greenhouse block effects. The seedlings were spaced 30-35 cm apart. After the trees reached full dormancy in December, they were undercut, bundled, and placed in an outdoor holding area. Individual trees were rinsed to remove adhering soil, and measured for height, diameter of the trunk just above the soil line, and total fresh weight. These measurements were combined to create four variables; 1) 10-month radius (diameter/2), 2) 10-month height, 3 ) 10-month fresh weight, and 4) 10-month growth index [(radius $)^{2} \times$ height $]$. 
Prior to further analysis, the data were examined for outliers. All variables for the greenhouse trial were standardized using a block-mean correction after preliminary analysis showed significant variation among blocks; no correction was needed for the nursery trial. Individual families were examined and family distributions were evaluated for individuals that were not healthy, dying, or expressed irregular measurements, with these individuals removed as outliers from the experiment. Using these criteria, 10 individuals were removed from the 2-month analysis and six additional individuals were removed from the 10-month analysis. In addition the terminal row in the nursery, containing 142 trees, received inadequate irrigation; results for these trees were judged unreliable and they were omitted from further analysis.

Regression of the natural log of the mean on the natural log of the standard deviation was preformed for each variable prior to statistical analysis. These regressions were significant for four variables, and power transformations (Fernandez, 1992) were applied to the values for 2-month radius, 2-month growth index, combined branch and trunk length, and 10-month radius.

Statistical analysis was conducted using SAS (SAS, 1999). Normality of residuals was tested using the Sharpiro-Wilks normality test for residuals. Differences in trait values due to current-generation inbreeding treatments were evaluated using a fixed effect analysis of variance (ANOVA) and SAS Procedure GLM (SAS, 1999). Tukey's Studentized multiple range test was used to establish significance levels among individual inbreeding treatments. Further resolution of the consequences of the currentgeneration inbreeding treatments were examined using a random effects model that included progenies nested in inbreeding treatments with SAS Type III mean square analysis (Table 1).

Table 1. Type III expected means square for Prunus domestica vegetative growth traits (height, radius, growth index, 2-month combined branch and trunk length, and 10-month fresh weight) measured at 2 and 10 months after germination with three inbreeding treatments $(\Delta \mathrm{F})$ : self-pollinated, full-sibling, non-related progenies.

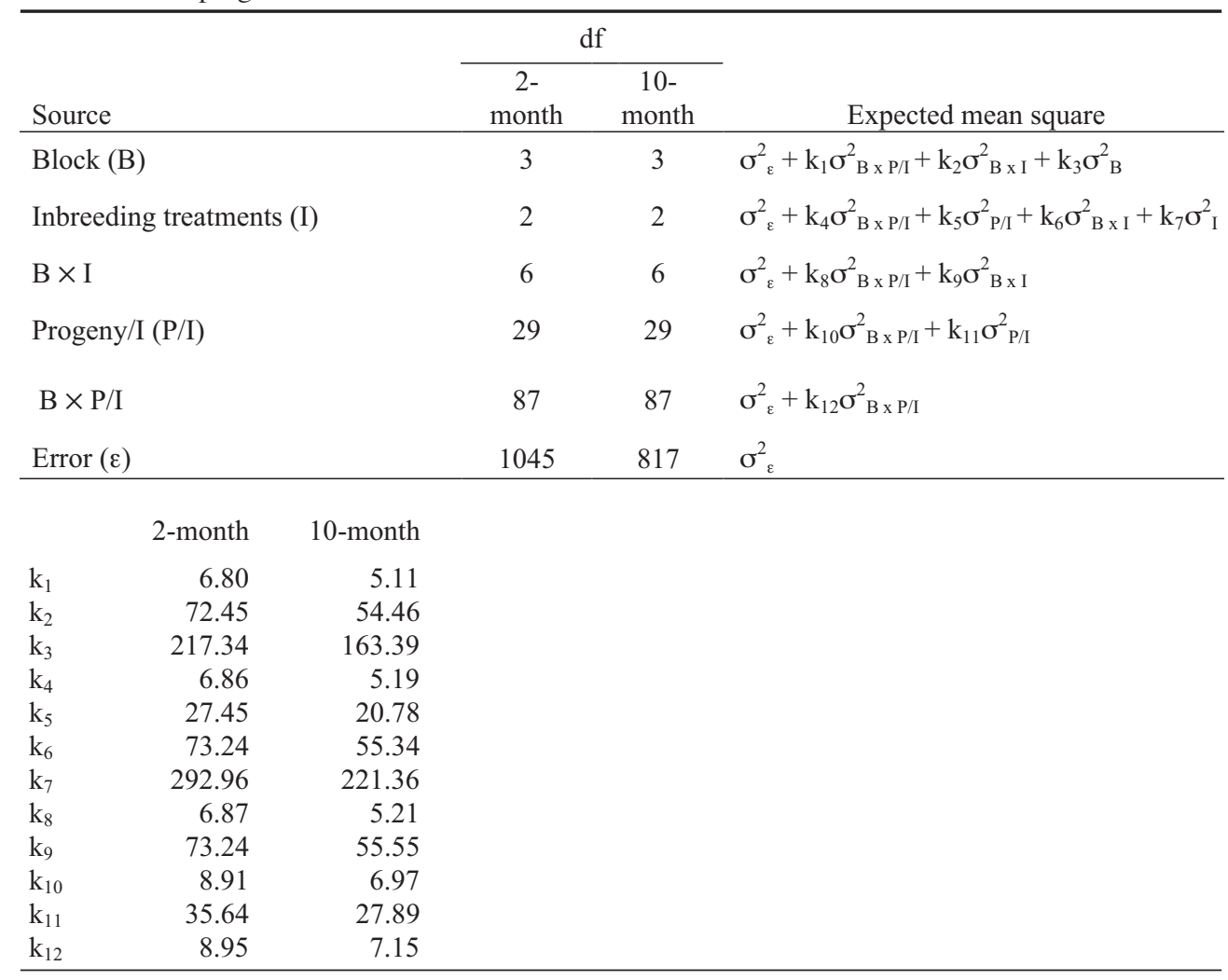

Regression analysis was used to evaluate the relationship between the current-generation $\mathrm{F}$ of the inbred treatments of selfed, full-sib, and nonrelated progenies compared to the progeny means for each growth trait. To evaluate the effect of accumulated inbreeding over multiple generations of mating with intervening cycles of selection the control set progenies and the nonrelated progenies growth trait means were compared to their accumulated Fs using regression analysis. As a test for nonlinearity of these relationships, stepwise regression was applied to force fit $\mathrm{F}$, and $\mathrm{F}^{2}$ was added to the regression model.

\section{Results and Discussion}

The percentage survival of seeds at germination was inversely related to current-generation inbreeding level (Table 2). Selfed progenies and full-sib progenies had relative germination rates of $74 \%$ and $85 \%$ compared to nonrelated progenies, and these differences resulted in highly significant heterogeneity among inbreeding treatments $\left(\chi^{2}=87.9, P<0.01\right)$. Percent germination for the control progenies was $82 \%$ compared to nonrelated progenies. This was very similar to that for full-sib progenies which was $85 \%$. Although inbreeding coefficients in the control progenies had accumulated over multiple generations with intervening cycles of selection, the consequences for survival at germination appear indistinquishable from that due to current generation inbreeding among full-sib progenies.

The mortality observed at germination may be due to the exposure of rare lethal recessive alleles in homozygous form or to an increase in the number of unfavorable recessive alleles expressed in homozygous form and consequent reduction in vigor of the embryo. Rare lethal alleles were responsible for low fecundity in $D$. melanogaster (Charlesworth and Charlesworth, 1987) and for reduced seed fill resulting in embryo death in many conifers ( Koelewijn et al., 1999; Williams and Savolainen, 1996). Depressed germination percentages due to inbreeding have been found in strawberry after three generations of selfing (Melville et al., 1980) and redwood after only one generation of selfing (Libby et al., 1981). This study does not distinguish the reason for the reduction in survival at germination of the inbred individuals. Regardless, early life-cycle mortality is expected to affect the results for metric traits scored later by removing some of the excessive homozygosity generated by inbreeding from the study population, thus reducing the effective $\mathrm{F}$ for the surviving individuals. Importantly, this natural selection pressure acting on seed at germination may reduce the magnitude of inbreeding depression expressed in seedling growth characteristics and later life-cycle stages.

The selective elimination of individuals that have increased 
Table 2. Percentage of germinated Prunus domestica seed in each inbreeding treatments (selfed, fullsibling, nonrelated, and control set progenies) and percentage of germination relative to the nonrelated progenies.

\begin{tabular}{lccc}
\hline Inbreeding level & $\begin{array}{c}\text { Inbreeding } \\
\text { coefficient }\end{array}$ & $\begin{array}{c}\text { Germinated seeds } \\
(\%)\end{array}$ & $\begin{array}{c}\text { Germination relative } \\
\text { to nonrelated } \\
\text { progenies }(\%)\end{array}$ \\
\hline Nonrelated progenies & 0 & 82 & 100 \\
Full-sib progenies & 0.25 & 70 & 85 \\
Selfed progenies & 0.50 & 61 & 74 \\
Control set progenies & 0.23 & 67 & 82 \\
\hline
\end{tabular}

pared to trait means for nonrelated progenies. Trait mean depression for full-sib progenies was greater for 10-month measurements than for traits measured at 2 months $(6 \%$ to $20 \%$ ), whereas the mean reduction for selfed progenies at 10 months $(13 \%$ to $28 \%$ ) was similar to traits measured at 2 months (Table 4). Of the traits measured in our experiment, the plant growth index, which combines both homozygosity or that express rare lethal recessive alleles due to inbreeding may provide an immediate benefit to the breeding program. Reduction in the frequency of highly unfavorable alleles could decrease the mortality at germination of future generations, improving the survival at germination for more inbred offspring. However, this type of purging is not expected to be effective in removing mildly unfavorable alleles from the population, perhaps increasing the magnitude of inbreeding depression for metric traits expressed in later generations. With advanced generations, the genetic drift that occurs in small populations, such as a breeding population, could also cause fixation of the some of the unfavorable alleles (Hedrick, 1994), permanently affecting selection limits.

Means for all seedling growth traits, measured at 2 months and 10 months, decreased as the level of current-generation inbreeding increased (Tables 3 and 4). Individual traits differed in their response to inbreeding, with those measured at 2 months expressing $1 \%$ to $9 \%$ depression for the full-sib progenies and $14 \%$ to $30 \%$ depression for the selfed progenies (Table 3 ) com- the height and the radius, was the best indicator of inbreeding depression for both 2- and 10-month measurements, suggesting that inbreeding affects a broad array of plant functions related to growth and vigor.

Selfed progenies differed significantly from both the full-sib progenies, and the nonrelated progenies $(\mathrm{df}=933 ; P<0.05)$ for all traits measured at 2 months using Tukey's Studentized multiple range test; full-sib progenies and nonrelated progenies did not differ significantly for the same traits. Results of the Tukey's test for all traits measured at 10 months indicate that the selfed progenies and the full-sib progenies no longer differed significantly from each other, but that both differed significantly from the nonrelated progenies $(\mathrm{df}=933 ; P<0.05)$.

The greater inbreeding depression observed for traits measured at 10 months may have been due to the different growth environments: the conditions in the greenhouse in the first 2 months were more favorable compared to the somewhat harsher conditions of the outdoor nursery in the remaining months. A similar result has been observed for loblolly pine (Pinus taeda

Table 3. Trait means (SD in parenthesis) and the percent decrease of trait means relative to the mean for progenies among nonrelated progenies for Prunus domestica vegetative growth variables (height, radius, growth index, and combined branch, and trunk length) at 2 months after germination.

\begin{tabular}{|c|c|c|c|c|c|c|c|c|c|}
\hline \multirow[b]{2}{*}{$\begin{array}{l}\text { Inbreeding } \\
\text { treatment }\end{array}$} & \multirow[b]{2}{*}{$\mathrm{n}$} & \multicolumn{2}{|c|}{$\begin{array}{l}\text { 2-month ht } \\
(\mathrm{mm})\end{array}$} & \multicolumn{2}{|c|}{$\begin{array}{l}\text { 2-month radius } \\
(\mathrm{mm})\end{array}$} & \multicolumn{2}{|c|}{$\begin{array}{l}\text { 2-month } \\
\text { growth index }\end{array}$} & \multicolumn{2}{|c|}{$\begin{array}{l}\text { Combined branch and trunk } \\
\text { length }(\mathrm{mm})\end{array}$} \\
\hline & & Mean & $\begin{array}{c}\text { Decrease } \\
(\%)\end{array}$ & Mean & $\begin{array}{c}\text { Decrease } \\
(\%)\end{array}$ & Mean & $\begin{array}{c}\text { Decrease } \\
(\%)\end{array}$ & Mean & $\begin{array}{c}\text { Decrease } \\
(\%)\end{array}$ \\
\hline $\begin{array}{l}\text { Nonrelated } \\
\text { progenies }\end{array}$ & 486 & 303 (112) & & $1.54(0.29)$ & & $814(481)$ & & 377 (178) & \\
\hline $\begin{array}{l}\text { Full-sib } \\
\text { progenies }\end{array}$ & 374 & $292(101)$ & 4 & $1.52(0.28)$ & 2 & $743(400)$ & 9 & $374(173)$ & 1 \\
\hline $\begin{array}{l}\text { Selfed } \\
\text { progenies }\end{array}$ & 313 & $251(126)$ & 17 & $1.33(0.37)$ & 14 & $567(464)$ & 30 & 317 (186) & 16 \\
\hline $\begin{array}{l}\text { Control set } \\
\text { progenies }\end{array}$ & 192 & $280(104)$ & 8 & $1.48(0.33)$ & 4 & 703 (419) & 14 & $341(162)$ & 9 \\
\hline
\end{tabular}

${ }^{\mathrm{z}}$ Growth index $=(\text { radius })^{2} \times$ height.

Table 4. Trait means (SD in parenthesis) and the percentage decrease of trait means relative to the mean for progenies among nonrelated progenies for Prunus domestica vegetative growth variables (height, radius, growth index, and fresh weight) at 10 months after germination.

\begin{tabular}{|c|c|c|c|c|c|c|c|c|c|}
\hline \multirow[b]{2}{*}{$\begin{array}{l}\text { Inbreeding } \\
\text { treatments }\end{array}$} & \multirow[b]{2}{*}{$\mathrm{n}$} & \multicolumn{2}{|c|}{$\begin{array}{l}10 \text {-month ht } \\
(\mathrm{cm})\end{array}$} & \multicolumn{2}{|c|}{$\begin{array}{l}\text { 10-month radius } \\
(\mathrm{mm})\end{array}$} & \multicolumn{2}{|c|}{$\begin{array}{l}\text { 10-month } \\
\text { growth index }\end{array}$} & \multicolumn{2}{|c|}{$\begin{array}{l}\text { 10-month } \\
\text { fresh wt }(\mathrm{g})\end{array}$} \\
\hline & & Mean & $\begin{array}{c}\text { Decrease } \\
(\%)\end{array}$ & Mean & $\begin{array}{c}\text { Decrease } \\
(\%)\end{array}$ & Mean & $\begin{array}{c}\text { Decrease } \\
(\%)\end{array}$ & Mean & $\begin{array}{c}\text { Decrease } \\
(\%)\end{array}$ \\
\hline $\begin{array}{l}\text { Nonrelated } \\
\text { progenies }\end{array}$ & 399 & $101(30)$ & & $8.2(1.8)$ & & $7818(4831)$ & & $229(124)$ & \\
\hline $\begin{array}{l}\text { Full-sib } \\
\text { progenies }\end{array}$ & 307 & $90(29)$ & 10 & $7.8(1.7)$ & 6 & $6258(4168)$ & 20 & $189(102)$ & 18 \\
\hline $\begin{array}{l}\text { Selfed } \\
\text { progenies }\end{array}$ & 239 & $86(35)$ & 15 & $7.1(2.2)$ & 13 & $5655(5002)$ & 28 & $175(131)$ & 24 \\
\hline $\begin{array}{l}\text { Control set } \\
\text { progenies }\end{array}$ & 177 & $99(32)$ & 2 & $7.9(1.8)$ & 4 & 7207 (4617) & 8 & 208 (118) & 9 \\
\hline
\end{tabular}

${ }^{2}$ Growth index $=(\text { radius })^{2} \times$ height. 
L.) seedlings, where less inbreeding depression was found for greenhouse seedling height compared to other studies of inbred loblolly pine grown outdoors (Sniezko and Zobel, 1987). In the harsher environment, selfed seedlings of redwood had a lower survival rate and an increase of inbreeding depression for height compared to the selfed seedlings from the same families grown in a more favorable environment (Libby et al., 1981).

The percent reduction in height for selfed and full-sib progenies at 10 months in the current study, $15 \%$ and $10 \%$, respectively, are similar to the percent inbreeding depression others have reported for inbred trees after one year of growth. Reduction of the mean height for inbred progenies ranged from $15 \%$ to $38 \%$ in other species; eucalyptus (Eucalyptus regnans F. Muell.), douglas-fir, ponderosa pine (Pinus ponderosa Laws.), and redwood (Griffin and Cotterill, 1988; Libby et. al. 1981; Sorensen, 1997; Sorensen and Miles, 1974).

Two-month height, radius, index, combined branch and trunk length; 10-month height, radius, index, and fresh weight differed significantly among the three current-generation inbreeding treatments (Tables 5 and 6). Blocks differed significantly for all traits evaluated at 2 months and there was a significant interaction between inbreeding treatment and block for 2-month height measurements. Differences among blocks were likely due to the fact that the seedlings continued growing throughout the measurement period, generating differences between those blocks scored early and late. No significant differences were detected among blocks for any trait measured at 10 months, nor were there detectable interactions among inbreeding treatments and blocks.

Further evaluation of the magnitude of inbreeding effects with a random effects ANOVA demonstrated that differences among the current-generation inbreeding treatments were not significant when progenies nested in inbreeding treatments were included in the ANOVA (Tables 7 and 8). Highly significant variances were found among progenies within inbreeding treatment for all growth traits $(\mathrm{df}=29 ; P<0.0001)$. The pooled variance among progenies within the inbreeding treatments for all traits was greater than the variance due to differing inbreeding treatments (Tables 7 and 8), with the variance among the progenies 4-100 times that of the variance among inbreeding treatments for the 2-month traits and 6-10 times greater for the 10-month traits. The large variance among progenies within inbreeding treatment may indicate that different parents responded differently to inbreeding (Sniezko and Zobel, 1987). However, variances of similar size attributed to families were detected for the nonrelated progenies, so this observation may just reflect the large genotypic variation present in the population itself.

Coefficients for regression of progeny means on current-generation $\mathrm{F}$ were significant $(P=0.0011-0.0232)$ and negative for all vegetative growth traits (Table 9). These findings are characteristic of inbreeding depression for metric traits (Falconer and Mackay, 1996). Stepwise regression analyses were performed for all traits by forcing $\mathrm{F}$ as an independent variable and then adding

Table 5. Analysis of variance for Prunus domestica vegetative growth traits (height, radius, growth index, and combined branch and trunk length) at 2 months after germination between inbreeding treatments (selfed, full-sibling, and nonrelated progenies).

\begin{tabular}{|c|c|c|c|c|c|c|c|c|c|}
\hline \multirow[b]{2}{*}{ Source } & \multirow[b]{2}{*}{ df } & \multicolumn{2}{|c|}{ 2-month ht } & \multicolumn{2}{|c|}{$\begin{array}{c}\text { 2-month } \\
\text { radius }\end{array}$} & \multicolumn{2}{|c|}{$\begin{array}{c}\text { 2-month growth } \\
\text { index }^{\mathrm{z}}\end{array}$} & \multicolumn{2}{|c|}{$\begin{array}{c}\text { Combined branch and } \\
\text { trunk length }\end{array}$} \\
\hline & & $\begin{array}{l}\text { Mean } \\
\text { square }\end{array}$ & $\mathrm{F}$ & $\begin{array}{l}\text { Mean } \\
\text { square }\end{array}$ & $\mathrm{F}$ & $\begin{array}{l}\text { Mean } \\
\text { square }\end{array}$ & $\mathrm{F}$ & $\begin{array}{l}\text { Mean } \\
\text { square }\end{array}$ & $\mathrm{F}$ \\
\hline Block & 3 & 321274 & $27.5^{* *}$ & 13.0 & $13.9^{* *}$ & 606 & $22.0^{* *}$ & 14.0 & $15.6^{* *}$ \\
\hline Inbreeding treatment & 2 & 267230 & $22.9^{* *}$ & 42.4 & $45.5^{* *}$ & 1115 & $40.6^{* *}$ & 17.8 & $19.9^{* *}$ \\
\hline $\begin{array}{l}\text { Inbreeding treatment } \\
\times \text { block }\end{array}$ & 6 & 26201 & $2.2^{*}$ & 1.1 & 1.2 & 51 & 1.9 & 0.9 & 1.1 \\
\hline Error & 1161 & 11697 & & 0.9 & & 27 & & 0.9 & \\
\hline
\end{tabular}

${ }^{\mathrm{z}}$ Growth index $=(\text { radius })^{2} \times$ height.

*,**P at 0.05 and 0.01 levels of significance, respectively.

Table 6. Analysis of variance for Prunus domestica vegetative growth traits (height, radius, growth index, and fresh weight) at 10 months after germination between inbreeding treatments (selfed, full-sibling, and nonrelated progenies).

\begin{tabular}{|c|c|c|c|c|c|c|c|c|c|}
\hline \multirow[b]{2}{*}{ Source } & \multirow[b]{2}{*}{ df } & \multicolumn{2}{|c|}{$\begin{array}{c}\text { 10-month } \\
\mathrm{ht}\end{array}$} & \multicolumn{2}{|c|}{$\begin{array}{l}10 \text {-month } \\
\text { radius }\end{array}$} & \multicolumn{2}{|c|}{$\begin{array}{l}\text { 10-month growth } \\
\text { index }\end{array}$} & \multicolumn{2}{|c|}{$\begin{array}{l}\text { 10-month } \\
\text { fresh wt }\end{array}$} \\
\hline & & $\begin{array}{l}\text { Mean } \\
\text { square }\end{array}$ & $\mathrm{F}$ & $\begin{array}{l}\text { Mean } \\
\text { square }\end{array}$ & $\mathrm{F}$ & $\begin{array}{c}\text { Mean } \\
\text { square }\end{array}$ & $\mathrm{F}$ & $\begin{array}{l}\text { Mean } \\
\text { square }\end{array}$ & $\mathrm{F}$ \\
\hline Block & 3 & 298 & 0.3 & 2548 & 0.9 & 12683163 & 0.6 & 20530 & 1.5 \\
\hline Inbreeding treatment & 2 & 20073 & $20.7^{* *}$ & 60630 & $20.3^{* *}$ & 407014753 & $18.6^{* *}$ & 260464 & $18.3^{* *}$ \\
\hline $\begin{array}{l}\text { Inbreeding treatment } \\
\times \text { block }\end{array}$ & 6 & 613 & 0.6 & 2484 & 0.8 & 16288983 & 0.8 & 13255 & 0.9 \\
\hline Error & 933 & 969 & & 2984 & & 21879820 & & 14203 & \\
\hline
\end{tabular}

${ }^{\mathrm{z}}$ Growth index $=(\text { radius })^{2} \times$ height.

${ }^{*}{ }^{* *} P$ at 0.05 and 0.01 levels of significance, respectively. 
Table 7. Mean squares and variance components for Prunus domestica vegetative growth traits (height, radius, growth index, and combined branch and trunk length) measured at 2 months after germination.

\begin{tabular}{lcccc}
\hline Source & 2 -month ht & 2-month radius & $\begin{array}{c}\text { 2-month growth } \\
\text { index }\end{array}$ & $\begin{array}{c}\text { Combined branch } \\
\text { and trunk length }\end{array}$ \\
\hline Block (B) & $294097^{* *}$ & $10.9^{*}$ & $541^{* * *}$ & $13.0^{* *}$ \\
Inbreeding treatment (I) & 93341 & 18.4 & 449 & 10.9 \\
$\mathrm{~B} \times \mathrm{I}$ & $24608^{*}$ & 1.2 & $51^{*}$ & 1.1 \\
Progenies/I (P/I) & $90213^{* *}$ & $6.8^{* *}$ & $218^{* *}$ & $6.7^{* *}$ \\
$\mathrm{~B} \times \mathrm{P} / \mathrm{I}$ & 10347 & 0.7 & 20 & 0.9 \\
\hline$\sigma^{2} \mathrm{I}$ & 25 & 0.043 & 0.83 & 0.018 \\
$\sigma^{2} \mathrm{~B} \times \mathrm{I}$ & 197 & 0.007 & 0.41 & 0.004 \\
$\sigma^{2} \mathrm{P} / \mathrm{I}$ & 2241 & 0.17 & 5.55 & 0.165 \\
$\sigma^{2} \mathrm{~B} \times \mathrm{P} / \mathrm{I}$ & 84 & 0 & 0 & 0.015 \\
$\sigma^{2}$ Error & 9599 & 0.79 & 22.70 & 0.734 \\
\hline${ }^{*}$ Growth index $=(\text { radius })^{2} \times$ height. & & &
\end{tabular}

Table 8. Mean squares and variance components for Prunus domestica vegetative growth traits (height, radius, growth index, and fresh weight) measured at 10 months after germination.

\begin{tabular}{|c|c|c|c|c|}
\hline Source & 10-month ht & $\begin{array}{l}10 \text {-month } \\
\text { radius }\end{array}$ & $\begin{array}{l}\text { 10-month growth } \\
\text { index }^{\mathrm{z}}\end{array}$ & $\begin{array}{l}\text { 10-month } \\
\text { fresh wt }\end{array}$ \\
\hline Block (B) & 1397 & 1893 & 14512038 & 18452 \\
\hline Inbreeding treatment (I) & 7653 & 23610 & 169382679 & 101037 \\
\hline $\mathrm{B} \times \mathrm{I}$ & 606 & 3862 & 22349626 & 18061 \\
\hline Progenies/I (P/I) & $5491^{* *}$ & $12949^{* *}$ & $102688316^{* *}$ & $62814^{* *}$ \\
\hline $\mathrm{B} \times \mathrm{P} / \mathrm{I}$ & $1049^{*}$ & 2521 & 18325004 & 11839 \\
\hline$\sigma^{2} I$ & 17 & 54 & 380384 & 203 \\
\hline$\sigma^{2} \mathrm{~B} \times \mathrm{I}$ & 0 & 23 & 67765 & 108 \\
\hline$\sigma^{2} \mathrm{P} / \mathrm{I}$ & 160 & 374 & 3024453 & 1827 \\
\hline$\sigma^{2} \mathrm{~B} \times \mathrm{P} / \mathrm{I}$ & 35 & 0 & 0 & 0 \\
\hline$\sigma^{2}$ Error & 797 & 2674 & 19287156 & 12656 \\
\hline
\end{tabular}

$\mathrm{F}^{2}$. The nonlinear component did not improve the fit of the model compared with regression of $\mathrm{F}$ alone, indicating that epistasis was not important in conditioning the genetic variance for these traits (Shaw, 1995; Williams and Savolainen, 1996)

Coefficients for regression of progeny means on the pedigree F accumulated over multiple generations with intervening cycles of selection were nonsignificant $(\mathrm{F}=0.09$ to 0.35$)$ for all of the vegetative growth traits (Table 10). The absence of any detectible relationships between pedigree $\mathrm{F}$ and trait values suggests that the intervening selection mitigated the effects of inbreeding depression (Ehiobu et al., 1989; Shaw, 1997). Selection may have eliminated unfavorable recessive alleles that were exposed by the inbreeding and increased the rate of change of the favorable allele frequency (Falconer and Mackay, 1996).
The results of the regression analysis for vegetative growth traits are contradictory to those for germination, where survival of the seed from the control progenies was decreased compared to the nonrelated progenies. Past selection may have mitigated inbreeding depression for seedling growth traits but not removed the unfavorable alleles affecting germination in this population.

The detection of inbreeding depression for vegetative growth traits, evaluated early in the growth cycle for $P$. domestica, suggests that similar depression may also be found for horticulturally important characteristics, such as fruit quality and yield, expressed in later life stages of the trees. The correlation of traits expressed in early and later life-cycle stages in populations affected by inbreeding depression has been studied in forestry breeding programs. Inbreeding depression for tree height increased slightly over 10 
Table 9. Regression analysis of 2-month and 10-month progeny Prunus domestica vegetative growth traits (height, radius, growth index, 2-month combined branch and trunk length, and 10-month fresh weight) means of the selfed, full-sibling and nonrelated progenies compared to their current season inbreeding coefficients (Fs).

\begin{tabular}{|c|c|c|c|c|c|}
\hline & & 2-month ht & 2-month radius & $\begin{array}{l}\text { 2-month } \\
\text { growth index }\end{array}$ & $\begin{array}{l}\text { Combined branch } \\
\text { and trunk length }\end{array}$ \\
\hline Source & df & Mean square & Mean square & Mean square & Mean square \\
\hline Block & 3 & $44212^{* * *}$ & $1.61^{* *}$ & $80.8^{* *}$ & $1.96^{* *}$ \\
\hline Regression & 1 & $23534^{*}$ & $4.65^{* *}$ & $111.2^{* *}$ & $1.69^{*}$ \\
\hline Error & 123 & 4074 & 0.31 & 10.0 & 0.32 \\
\hline$\beta$ & & -65.4 & -0.92 & -4.49 & -0.55 \\
\hline$R^{2}$ & & 0.24 & 0.20 & 0.22 & 0.16 \\
\hline
\end{tabular}

\begin{tabular}{|c|c|c|c|c|c|}
\hline & & 10-month ht & 10-month radius & $\begin{array}{c}\text { 10-month } \\
\text { growth index }\end{array}$ & $\begin{array}{c}\text { 10-month } \\
\text { fresh wt }\end{array}$ \\
\hline Source & df & Mean square & Mean square & Mean square & Mean square \\
\hline$\overline{\text { Block }}$ & 3 & 276 & 359 & 2750972 & 3457 \\
\hline Regression & 1 & $2588^{* *}$ & $9003^{* *}$ & $55694260^{* *}$ & $36239^{* *}$ \\
\hline Error & 123 & 367 & 921 & 6771123 & 4111 \\
\hline$\beta$ & & -21.7 & -40.5 & -3182 & -81.2 \\
\hline$R^{2}$ & & 0.07 & 0.08 & 0.07 & 0.08 \\
\hline
\end{tabular}

Table 10. Regression analysis of 2-month and 10-month progeny Prunus domestica vegetative trait (height, radius, growth index, 2-month combined branch and trunk length, and 10-month fresh weight) means of the control set progenies combined with the nonrelated progenies compared to their inbreeding coefficients (Fs) accumulated over generations with intervening cycles of selection.

\begin{tabular}{|c|c|c|c|c|c|}
\hline & & 2-month ht & 2-month radius & $\begin{array}{l}\text { 2-month } \\
\text { growth index }\end{array}$ & $\begin{array}{l}\text { Combined branch } \\
\text { and trunk length }\end{array}$ \\
\hline Source & df & $\overline{\text { Mean square }}$ & $\overline{\text { Mean square }}$ & $\overline{\text { Mean square }}$ & Mean square \\
\hline Block & 3 & $21696^{* *}$ & 1.04 & $45.3^{*}$ & 1.08 \\
\hline Regression & 1 & 22 & 0.02 & 0.0 & 0.00 \\
\hline Error & 47 & 4631 & 0.50 & 13.4 & 0.38 \\
\hline$\beta$ & & 8.28 & -0.22 & 0.01 & -0.09 \\
\hline \multirow[t]{2}{*}{$R^{2}$} & & 0.23 & 0.12 & 0.18 & 0.15 \\
\hline & & 10-month ht & 10 -month radius & $\begin{array}{l}\text { 10-month } \\
\text { growth index }\end{array}$ & $\begin{array}{l}\text { 10-month } \\
\text { fresh wt }\end{array}$ \\
\hline Source & df & $\overline{\text { Mean square }}$ & Mean square & $\overline{\text { Mean square }}$ & Mean square \\
\hline Block & 3 & 232 & 924 & 4496736 & 4769 \\
\hline Regression & 1 & 1.0 & 1515 & 836707 & 10564 \\
\hline Error & 47 & 283 & 899 & 6245402 & 4415 \\
\hline$\beta$ & & 1.81 & -69.33 & -5152.8 & -183.1 \\
\hline$R^{2}$ & & 0.05 & 0.09 & 0.07 & 0.11 \\
\hline
\end{tabular}

${ }^{z}$ Growth index $=(\text { radius })^{2} \times$ height.

${ }^{* * *} P$ at 0.05 and 0.01 levels of significance, respectively. years in douglas-fir, ponderosa pine, and noble fir (Abies procera Rehd.) (Sorensen and Miles, 1982) but in scots pine (Pinus sylvestris $\mathrm{L}$.) the effects of inbreeding on height diminished in later years (Koelewijn et al., 1999). Koelewijn et al. (1999) theorized that strong deleterious alleles and lethals in scots pine were expressed in early stages of growth while mildly deleterious alleles were expressed in later stages. It is also possible that the decrease of inbreeding depression for scots pine may have been due to the high mortality over the years of selfed seedlings compared to nonrelated seedlings. If a similar pattern were followed in P.domestica, early evaluation and culling based on tree structure, height, and wood strength could reduce the number of individuals with poor vigor, but this selection may not mitigate inbreeding depression for other desired traits such as fruit yield and fruit quality that are expressed later in the selection cycle.

Although inbreeding depression was found for all traits measured in our study, the expression of trait mean depression differed substantially among the characteristics evaluated and the environment in which they were grown. The strong selection pressure observed at the germination stage for $P$. domestica may reduce the excess homozygosity generated by inbreeding in chromosomal regions surrounding the affected loci (Stephan and Langley, 1998), but the presence of residual trait mean depression for seedling growth characteristics suggests that purging of deleterious or mildly deleterious alleles at this stage is far from complete. Taken together, these results suggest that an effective breeding strategy for this crop should include implementation of a system for co-ancestry control that will limit matings among relatives to control the rate at which potentially deleterious homozygosity accumulates.

\section{Literature Cited}

Bortiri, E., S.H. Oh, J. Jiang, S. Baggett, A. Granger, C. Weeks, M. Buckingham, D. Potter, and D.E. Parfitt. 2001. Phylogeny and systematics of Prunus (Rosaceae) as determined by sequence analysis of ITS and the chloroplast trnL-trnF spacerDNA. Systematic Bot. 26(4):797-807.

Bringhurst, R.S. and V. Voth. 1984. Breeding octoploid strawberries. Iowa State J. Res. 58(4):371-381.

Charlesworth, D. and B. Charlesworth. 1987. Inbreeding depression and its evolutionary consequences. Annu. Rev. Ecol. Systems 18:237-268. 
Cornelius, P.L. and J.W. Dudley. 1974. Effects of inbreeding by selfing and full-sib mating in a maize population. Crop Sci. 14:815-819.

Cram, W.H. 1984. Some effects of self-, cross-, and open-pollinations in Picea pungens. Can. J. Bot. 62:392-395.

Ehiobu, N.G., M.E. Goddard, and J.F. Taylor. 1989. Effect of rate of inbreeding on inbreeding depression in Drosophila melanogaster. Theor. Appl. Genet. 77:123-127.

Falconer, D.S. and T.C. Mackay. 1996. Introduction to quantitative genetics. $4^{\text {th }}$ ed. Longman, Edinburgh Gate, England.

Fehr, W.R. 1991. Principles of cultivar development: Vol. 1, Theory and technique. Macmillan, New York.

Fernandez, G. 1992. Residual analysis and data transformations: Important tools in statistical analysis. HortScience 27:297-300.

Griffin, A.R. and P.P. Cotterill 1988. Genetic variation in growth of outcrossed, selfed and open-pollinated progenies of Eucalyptus regans and some implications for breeding strategy. Silvae Genetica 37(3-4):124-131.

Hedrick, P.W. 1994. Purging inbreeding depression and the probability of extinction: Full-sib mating. Heredity 73:363-372.

Hedrick, P.W., O. Savolainen, and K. Kärkkäinen. 1999. Factors influencing the extent of inbreeding depression: An example from scots pine. Heredity 82:441-450.

Hrotkó, K. and L. Magyar. 1998. Inbreeding of Prunus mahaleb. Acta Hort. 486:393-400.

Jones, J.S. and E.T. Bingham. 1995. Inbreeding depression in alfalfa and cross-pollinated crops. Plant Breeding Rev. 13:209-233.

Koelewijn, H.P., V. Koski, and O. Savolainen. 1999. Magnitude and timing of inbreeding depression in scots pine (Pinus sylvestris L.). Evolution 53:758-768.

Libby, W.J. and C.C. Cockerham. 1980. Random non-contiguous plots in interlocking field layouts. Silvae Genetica 29:183-190.

Libby, W.J., B.G. McCutchan, and C.I. Millar. 1981. Inbreeding depres- sion in selfs of redwood. Silvae Genetica 30(1):15-25.

Melville, A.H., G.J. Galletta, A.D. Draper, and T.J. Ng. 1980. Seed germination and early seedling vigor in progenies of inbred strawberry selections. HortScience 15:749-750.

Morrow, E.B. and G.M. Darrow. 1952. Effects of limited inbreeding in strawberries. Proc. Amer. Soc. Hort. Sci. 59:269-276.

Mowrey, B.D. and D.J. Werner. 1990. Phylogenetic relationships among species of Prunus as inferred by isozyme markers. Theor. Appl. Genet. 80:129-133.

Shaw, D.V. 1995. Comparison of ancestral and current-generation inbreeding in an experimental strawberry breeding population. Theor. Appl. Genet. 90:237-241.

Shaw, D.V. 1997. Trait mean depression for second-generation inbred strawberry populations with and without parent selection. Theor. Appl. Genet. 95:261-264.

Sniezko, R.A. and B.J. Zobel. 1987. Seedling height and diameter variation of various degrees of inbred and outcross progenies of loblolly pine. Silvae Genetica 37(2):50-60.

Sorensen, F.P. and R.S. Miles. 1974. Self-pollination effects on douglas-fir and ponderosa pine seeds and seedlings. Silvea Genetica 23(5):135-138.

Sorensen, F.P. and R.S. Miles. 1982. Inbreeding depression in height, height growth, and survival of douglas-fir, ponderosa pine, and noble fir to 10 years of age. Forest Sci. 28(2):283-292.

Sorensen, F.P. 1997. Effects of sib mating and wind pollination on nursery seedling size, growth components, and phenology of douglas fir seed orchard progenies. Can. J. For. Res. 27:557-566.

Stephan, W. and C.H. Langley. 1998. DNA polymorphism in Lycopersicon and crossing-over per physical length. Genetics 150:15851593.

Williams, C.G. and O. Savolainen. 1996. Inbreeding depression in conifers: Implications for breeding strategy. Forest Sci. 42(1):102-117. 